\title{
Employment Protection Legislation in Russia: Regional Enforcement and Labour Market Outc omes
}

V. Gimpelson (CLMS, Higher School of Ec onomics, Moscow)

R. Kapeliushnikov (C LMS, Higher School of Ec onomic s, Mosc ow)

A. Lukiya nova (CLMS, Higher School of Economics, Mosc ow)

Berlin, September 2009 


\title{
Employment Protection Legislation in Russia: Regional Enforcement and Labour Market Outcomes $^{1}$
}

(Is Saltykov-Tchedrin's Hypothesis Still Valid?)

\author{
V.Gimpelson, R.Kapeliushnikov, A.Lukiyanova \\ CLMS, Higher School of Economics
}

The efficiency of the labour market critically depends on the design of its institutions with employment protection legislation (EPL) playing a special role here. However, since formal laws can be observed or ignored to varying degrees, the actual enforcement regime shapes incentives and constraints. Most of the studies exploring EPL effects on labour market performance implicitly assume that EPL compliance is near to complete and therefore all firms bear full adjustment costs incurred by the regulations. This seems to be a very strong assumption for any country but it sounds especially strong and hardly plausible for developing and transition economies. But if compliance and enforcement varies widely across regions/cities or segments of firms, then this variation is likely to cause variation in performance. This paper looks at Russia in particular. The main idea of this paper is to reveal and describe cross-regional and inter-temporal variation in EPL enforcement and to explore empirically whether it is translated into regional labour market outcomes. The paper employs unique data set based on the State Labour Inspectorate data and the Supreme court statistics on labour disputes.

JEL Codes: J21, J23, J52, K31, R23

Key words: employment protection regulations, enforcement, employment, unemployment, regional labor markets

Version of September 12, 2009

\footnotetext{
${ }^{1}$ The paper was written as a part of the CLMS efforts within the ESCIRRU project funded by the EC. The authors are grateful to Hartmut Lehmann, John Earle, Stefano Scarpetta, Nina Vishnevskaya. Earlier results of the study were presented at the CLMS-HSE seminar (HSE, Moscow, Feb 2008), the ESCIRRU interim workshop (DIW, Berlin, March 2008) the IX International Conference "Modernization of the Economy and Globalization", (Moscow, April 2008), the OECD informal workshop on the Russian Labour Market (OECD, Paris, April 2008).
} 
«The stringency of Russian laws is offset by their non-observance»

(Attributed to M.Saltykov-Tchedrin) ${ }^{2}$

\section{Introduction}

M.Saltykov-Tchedrin's famous thesis, if still valid, has profound political and economic implications. Since formal laws can be observed or ignored to varying degrees, the actual enforcement regime shapes incentives and constraints. Stringent laws coupled with weak and discretionary enforcement allow for larger variation in this environment, bringing about uncertainty and affecting all aspects of economic, political and social life. This paper is about that segment of the legislation that shapes labour market behaviour and outcomes.

The efficiency of the labour market depends, among other things, on the design of its institutions, and the employment protection legislation (EPL) rules play a special role here. These regulations introduce a specific tax on firings, shifting the labour demand curve downwards. The tentative negative association between the EPL stringency and labour market performance has become a focus in quickly expanding literature that started with Lazear's (1990) seminal paper. ${ }^{3}$

Theoretically, all EPL-related tentative effects seem obvious. However, existing empirical arguments supporting these claims have been quite ambiguous. Regression coefficients for indexes reflecting EPL stringency are often insignificant or even have the unexpected sign. There are various reasons for this; they include various measurement problems, potential wage flexibility, the fact that inflows into employment and outflows from it may mutually offset each other, relatively little variation in the EPL indicators across countries and over time, etc. However, one of the key issues emerging in this context is to what degree the adopted regulations are actually enforced. In other words, what is the scale of the gap between the law and its practical application? Even very strict rules embedded in

\footnotetext{
${ }^{2}$ A famous Russian writer (1826-1889). He also served as a governor in one of the provinces of the Russian Empire.

${ }^{3}$ E.Lazear. Job Security and Employment. The Quarterly Journal of Economics, Vol.105, No.3 (Aug.1990), 699-726.
} 
formal laws may have little or no effect at all if they are widely circumvented or ignored. ${ }^{4}$ Most of the studies exploring EPL effects on labour market performance implicitly assume that EPL compliance is near to complete and therefore all firms bear full adjustment costs incurred by the regulations. This seems to be a very strong assumption for any country but it sounds especially strong and hardly plausible if we deal with developing or transition economies, which are notorious for weak institutions and poor law enforcement. But if enforcement is far from being complete and the degree of compliance varies widely across regions/cities or segments of firms, then this variation in enforcement/compliance emerges as a factor, ultimately causing variation in performance. In such a setting, the degree of actual enforcement can become more important in shaping labour market performance than the formal stringency of legislated rules which exist on paper only. This is what we may call "Saltykov-Tchedrin's hypothesis."

This paper looks at Russia in particular. There are a few reasons justifying such a choice. First, the EPL stringency in Russia is considered as very high while law enforcement in general tends to be low. Second, Russia is a huge country spanning 11 time zones with very heterogeneous regions. Institutional capacity to enforce laws and culture of law compliance across regions and sub-populations vary significantly. All this may result in actual enforcement being close to non-existent in some regions and close to complete in others. The emerging variation in enforcement is likely to determine the rigidity level in regional labour markets, affecting their performance. Third, to the best of our knowledge, any EPL effects in transition countries have never been rigorously researched.

The main idea of this paper is to reveal and describe cross-regional variation in EPL enforcement and to explore empirically whether it is translated into regional labour market outcomes.

The paper consists of the introduction, 6 sections, and the conclusion. It is structured in the following manner. Section 2 is a brief overview of the literature on EPL and EPL enforcement. The third section discusses properties of job protection and its enforcement in the Russian Federation. Here we analyze nominal and actual stringency in job protection institutions. In Section 4 we present our research methodology, including the set of

\footnotetext{
${ }^{4}$ Why this gap does emerge is an intriguing issue for study but remains largely outside the scope of this paper. Bad laws? Bad enforcement agencies? Bad culture? A mix of everything?
} 
hypotheses to be tested and our empirical strategy. Data issues are the focus of Section 5. Section 6 deals with cross-regional variation in the EPL enforcement and compliance. Section 7 outlines and discusses the econometric estimation results of EPL enforcement impacts on labour market performance. The conclusion summarizes main findings and suggests further research possibilities.

\section{Literature on the EPL enforcement}

Empirical literature dealing with effects of enforcement is sparse. This shortage can partially be explained by the fact that developed capitalist economies are usually considered to have a high degree of law observance and strictly following the rule of law. If the gap between written laws and their actual observance is small, then non-enforcement will hardly cause any significant changes in labour market outcomes at the aggregate level. But even when law enforcement is widely considered incomplete and variable, measuring to what degree actual enforcement deviates from the normative state is always a difficult task.

OECD experts recognize the problem but come short of simply stating this fact. "Employment protection regulation, a set of rules governing the hiring and firing process, can be provided through both labour legislation and collective bargaining agreements. In addition, it is important to distinguish these rules from practice, which brings in the enforcement dimension. Therefore, when discussing the extent of employment protection, judicial practices and court interpretations of legislative and contractual rules have to be taken into account as well." 5 The World Bank report on job opportunities in transition economies directly states that "EPL is not fully enforced in many of the transition countries". It suggests that such countries "need to focus more on credibly enforceable laws as opposed to 'paper protections', which at best protect a limited share of formal sector workers." ${ }^{, 7}$ However, the report provides little empirical evidence for this fact.

Large developing and transition economies can be good examples for studying the effects of enforcement. First, any large country is likely to have more heterogeneity in all dimensions and, therefore, more variation in enforcement and compliance than a small

\footnotetext{
${ }^{5}$ Employment Outlook, OECD, 2004, p.64

${ }^{6}$ Enhancing Job Opportunities. Eastern Europe and the Former Soviet Union, The World Bank, 2005, p. 211

${ }^{7}$ Ibid, p. 213
} 
country may demonstrate, other things being equal. Second, developing and transition economies are known for having much weaker institutional capacities than mature capitalist economies do. Weak institutions are a systemic feature of these economies. Often these capacities within a country depend on constellations of various regional/local political or cultural factors, which transform the country's institutional context into a kind of patchwork. These factors may not just contribute to incomplete enforcement, but also explain higher variation in EPL enforcement. All this motivates choosing a developing or a transition economy as a good candidate for more scrupulous study. Not surprisingly, Russia and Brasil are probably among the top choices for such study.

\subsection{Brasil}

To the best of our knowledge, the only empirical studies focusing on how variation in EPL enforcement can influence labour market efficiency are presented in two recent papers by Almeida and Carneiro. They both look at Brasil and test effects of non-enforcement.

In the first paper, Almeida and Carneiro (2005) investigate how enforcement of labor regulation affects the firm's use of informal employment and its impact on firm performance across Brasilian states. They conclude that in areas with stricter law enforcement firms employ a smaller amount of informal labour. But reductions in the firm's access to unregulated labor are not costless, since stricter enforcement decreases average wages, productivity and investment. ${ }^{8}$

In the follow-up paper, Almeida and Carneiro (2007) use city-level data to explore an EPL enforcement impacts on unemployment and inequality. ${ }^{9}$ Again, stricter enforcement increases proportions of formal employment and reduces income inequality. The price paid for this is in higher unemployment and lower formal wage premium.

\subsection{Russia}

Though Russia has been known for a long time as a country where law observance in general is highly problematic, this issue has never been a subject for in-depth empirical and

8 R.Almeida and P.Carneiro. Enforcement of Regulation, Informal Labor, and Firm Performance. IZA DP 1759, September 2005.

9 R.Almeida and P.Carneiro (2007) Inequality and Employment in a Dual Economy: Enforcement of Labor Regulation in Brazil, IZA DP No. 3094, October 2007. 
econometric research by economists. This conclusion holds true for any area of law we discuss.

There have been few special studies of EPL enforcement in Russia so far and there is very little evidence on that dimension of enforcement. ${ }^{10}$ Vishnevskaya and Kapeliushnikov analyzed differences in enforcement of employment protection legislation (EPL) across Russian regions using the same data that we do in this paper. Authors reveal substantial differences in the effectiveness of enforcement of EPL across Russian regions. The EPL violations are more often reported in the northern territories and in the ethnic republics. Regions with a more diversified economy and with a tighter local labour market demonstrate lower probability of reporting EPL violation. ${ }^{11}$ Using data from a special survey of judges in all Russian regions, Gimpelson and Kapeliushnikov focused on the role of judiciary in EPL enforcement. $^{12}$ They also underlined significant variation in applying the labour law contingent upon region, firm size, and segment of the law. However, the impact of incomplete enforcement on labour market performance has yet be studied.

A work by Lambert-Mogilyansky, Sonin and Zhuravskaya (2007) comes closest to the issue of variable enforcement and its outcomes. They study judicial bias in enforcement of bankruptcy regulations across Russian regions. ${ }^{13}$ As they show, such bias exists, tends to be politically motivated, and is important in shaping performance of firms under reorganization.

10 Eamets and Masso suggest that weak enforcement is typical for all countries in the transition including the Baltics, though the latter are already in the EU. Eamets R., J.Masso, Labour Market Flexibility and Employment Protection Regulation in the Baltic States, Discussion Paper No. 1147, May 2004

11 Vishnevskaya N., Kapelyushnikov R. The EPL Enforcement in Russia: Coverage, Dynamics, Interregional Differentiation. Working paper WP3/2007/02. Moscow: State University - Higher

School of Economics, 2007. - 80 p. (in Russian).

${ }^{12}$ Gimpelson V. and R. Kapeliushnikov. Applying Labour Law in Russia: Role of Judiciary. CLMS-HSE, 2008 (mimeo)

${ }^{13}$ Lambert-Mogiliansky A., K. Sonin, E. Zhuravskaya. Are Russian Commercial Courts Biased? Evidence from a Bankruptcy Law Transplant. Working Paper No 99, CEFIR / NES Working Paper series. 


\section{Labour Market Regulations and Their Enforcement}

Labour Market Regulations in Russia

Major labour market regulations that form the core of EPL are brought together and fixed in the Labour Code (LC) of the Russian Federation. The current LC was enacted in 2002 in order to replace the Code of Laws for Labour which had been in action continuously - though with multiple amendments - since Soviet times. Despite the fact that the main motivation for reforming the labour code in 2001 was to bring more flexibility in the legislative framework for the labour market and to pull employment relations out of the dark, the new LC basically inherited all the major rigidities that marked the previous legislation.

What do major EPL provisions say about costs of hiring and firing labour? The LC stipulates that in case of firings for economic reasons, employees have to be notified at least 2 months in advance. Additionally, they have to be paid compensation with severance pay equal to 2-3 average monthly wages. For workers living in the Northern and other remote (Far Eastern, e.g.) regions or regions with unfavourable climate conditions, severance pay can rise up to 6 average monthly wages. If monetary costs associated with advance notice are added to the severance pay, the employer's borne costs can make up to 9 average monthly wages (see Table A1 in the Appendix). In Russia, firing costs are flat along the tenure. This makes firing a newcomer as costly as firing a long-time incumbent with a large stock of firm-specific human capital accumulated over the long tenure. Even in the OECD countries with the most rigid labour markets (like Italy, France or Spain) firing costs for short-tenured workers are quite low, while these costs increase exponentially for dismissals of longtenured employees, making them far too costly. ${ }^{14}$ Another important EPL component regulates the use of fixed-term contracts. In Russia, the use of non-permanent labour contracts is legislatively limited with a closed list of legitimate reasons. The 2001 LC brought some ambiguity into their legally allowed use, providing employers with some hope for more flexibility. However, this hope was offset in 2004 by constraining interpretations given by the RF Supreme Court and follow-up amendments to the LC adopted in 2006. These clarifications restricted employers in using more flexible contractual arrangements even further.

${ }^{14}$ OECD Employment Outlook, OECD, 1999, Paris, Chapter 2. 
We can sum up the picture of the Russian EPL using various integral EPL indices that allow placement in a cross-country context. Whatever of the existing indices we choose, they confirm that the Russian EPL, as written in the law, is among the most stringent in the world. For example, on the OECD EPL scale Russia gets 3,6 scores against 2,0 on average for the OECD countries, 2,4 - for the EC countries, and 2,5 - for the transition countries in general (a higher score corresponds to more stringent legislation). ${ }^{15}$ The World Bank in its "Doing Business"-2007 survey estimated the rigidity of employment (rigidity of hirings, firings, and working hours) in Russia, assigning 44 scores against 30,8 for the OECD. ${ }^{16}$ The deviation from other countries emerges even stronger if we refer to indices suggested by Botero et al (2004). In this case, Russia earns a value of 0,83 against the median value of $0,44 .{ }^{17}$ This ranks Russia first on the list of the countries with the most rigid EPL.

So far we have discussed the nominal EPL rigidity under the assumptions that these formal regulations are enforced fully and unconditionally. However, this is not always true everywhere, and in transition countries this is often far from being true. Assuming that countries differ in law compliance, we can suggest a simple typology presented as Table 1.

Table 1. The Simple Typology of Labour Markets

\begin{tabular}{|c|c|c|}
\hline Formal stringency of EPL rules & \multicolumn{2}{|c|}{ Effectiveness of EPL enforcement } \\
\cline { 2 - 3 } & High & Low \\
\hline High & 1 & $\mathbf{2}$ \\
& (Continental Europe: & (Russia, CIS countries, \\
& Bermany, France, ...) & 4 \\
\hline Low & 3 & \\
& (Anglo-Saxon countries: & \\
\hline
\end{tabular}

This table, adopted from Kapeliushnikov (2004), places Russia into a group of countries with very stringent but poorly observed EPL rules. If this characterization is true (and below we will provide additional survey and statistical evidence for this), then the degree of EPL

\footnotetext{
${ }^{15}$ See Employment Outlook 2004, OECD, Paris. Estimates for Russia based on the OECD methodology are provided by N.Vishnevskaya

${ }^{16} \mathrm{http}$ ://www.doingbusiness.org/ExploreTopics/EmployingWorkers

${ }^{17}$ Botero, J., S. Djankov, R. La Porta, F. Lopez-de-Silanes, A. Shleifer. The Regulation of Labor, The Quarterly Journal of Economics, Nov. 2004.
} 
compliance becomes crucial, while formal stringency defines boundaries within which actual compliance may vary. As a result, the degree of actual compliance to laws instead of formal rigidity of legislation may become a major measure of real labour market flexibility. The actual degree of enforcement comes to the forefront of research efforts in evaluating the impact of employment adjustment costs.

EPL Enforcement in Russia: Dimensions and Institutions

In Russia, EPL regulations are fixed by the federal legislation (the Labour Code) and are uniform across all regions. However, these rules are applied and enforced always regionally (or even sub-regionally or locally). The degree of EPL observance depends on a complex constellation of regional/local factors, which are usually hard to administer from a remote centre. Among these factors are structural (some sectors of the economy show higher propensity to observe the law than the others, e.g. large firms vs small ones), cultural (culture of law obedience and the association between law obedience and education), institutional (capacity of local institutions to monitor law observance, to detect breach of the law and to punish law breakers), political (in some cases political authorities demonstrate higher propensity for political intervention into EPL enforcement that in others). All this results in a variable gap between formal rules and their actual observance.

Three major dimensions of variation in the enforcement are worth mentioning.

The first relates to the coverage of employed population by the EPL. The EPL in full usually applies to formal sector firms only if they are above a particular size. ${ }^{18}$ This takes small firms, individual entrepreneurs, self-employed, and those hired by other individuals (one may consider this heterogeneous group as the informal sector) out of the EPL regulations. A high proportion of the informal sector in the economy reduces effective coverage and therefore increases actual labour market flexibility. In the Russian context, the proportion of "large and medium sized firms" (L\&M firms) in the total employment can be interpreted as an approximate measure (more precisely, for the upper bound) of effective EPL coverage. ${ }^{19}$

${ }^{18}$ Boeri, T. and Jimeno, J. (2005), "The Effects of Employment Protection: Learning from Variable Enforcement", European Economic Review, 49(8).

19 So called large and medium sized firms make a special group which is more closely monitored by regulatory and tax authorities. They are also obliged to fill in monthly 
The second dimension gauges the institutional capacity of law enforcement agencies, which determines supply and quality of enforcement-related services. Here one could mention the density of labour inspectorate offices, the number of inspectors standardized with respect to employment or population in the region. These variables affect ability of the labour inspectorate to undertake inspection missions, to detect law violations, to restore justice, and finally to punish discovered violators. Another indicator relates to the institutional capacity of courts to deal with labour disputes filed to the judiciary system. It can be measured by the number of judges available for trying labour disputes or the total costs of using judiciary for plaintiffs. Low institutional capacity reduces probability of detecting violations and therefore makes non-observance less costly, therefore increasing defacto flexibility in the labour market.

The third dimension concerns the demand for enforcement, which comes from workers (or trade unions) and employers. It corresponds to their propensity to raise voice for better enforcement. The enforcement activity of labour inspectorate and that of courts can be initiated by voice of those whose rights are (or were) violated. Number of legal cases on labour disputes filed to courts is one in the family of such measures. A stronger voice calling for better enforcement increases the degree of EPL observance. The activity of trade unions also partially contributes to better enforcement through monitoring of law observance, activating workers' voice against EPL violations, providing legal assistance to workers whose rights were violated, etc.

In sum, the probability of being caught for non-compliance depends on institutional capacity of special agencies responsible for monitoring law compliance of firms (detecting and punishing violators by incurring them monetary penalties), and on firm characteristics (such a size, sector, and legal status), and activities of labour market players (employers and employees).

In Russia, such an agency, called the State Labour Inspectorate (LI), is a part of the Federal Service for Labour and Employment (Rostrud). Given the size of the country, the LI has its offices in all regions, and then its activity is further decentralized to the local level. Rights and obligations of the LI are regulated by the Labour Code; the latter contains a special chapter that describes functions and authority of the labour inspectorate.

statistical reports. The strict definition of these firms is quite complex but, roughly speaking, these are largely those employing $50+$ workers. 
The main LI objective is to monitor the enforcement of all labour regulations concerning hirings, firings, pay, and safety. However, the Labour Code provides the inspectorate with executive authority extending far beyond simple monitoring. The LI runs regular (planned in advance) and extraordinary control missions. Every firm is obliged to execute orders or requests issued by the LI. Otherwise, the LI inspectors can file the case to a local court office or to involve the prosecutor's office into the conflict. The LI enjoys significant discretion in deciding what labour regulations to monitor, in what firms, and when. The LI decides what firm and when to check but it may allocate inspectors after workers' complaints or after a prosecutor's office call. According to the law, all firms, regardless of the size, ownership and legal status are accountable to the LI for any labour related issues. All this endows the labour inspectorate with significant powers in enforcing labour regulations and in intervening in employer-employee relations.

Though jurisprudence can potentially play a very important role in enforcing the EPL provisions because employers can be sanctioned for non-respect to these rules, its effect is conditional upon a number of factors.

First, judicial intervention assumes that workers are ready to defend their rights and interests in courts. Opportunity costs of appealing to judiciary can strongly affect the propensity of workers to file their case to a court. For example, total costs of filing a case (including proximity to court office, complexity of filing the case, pay for lawyer's services, duration of waiting for judge's decision, belief in fairness of the court, etc,) affect workers' propensity to apply to judiciary. Moreover, the costs are likely to vary considerably across localities.

Second, these provisions are subject to court interpretations, which may constitute a major (but often hidden) source of variation in the EPL strictness both across regions and over time. As some recent studies suggest, the jurisprudence may be affected by underlying labour market conditions. For instance, judge's decisions may be particularly unfavourable to employers when unemployment is high. ${ }^{20}$

${ }^{20}$ Ichino, Andrea, Michele Polo, and Enrico Rettore. "Are Judges Biased by Labor Market Conditions?" European Economic Review, 2003, 47 (5) 913 - 944; G.Bertola, T.Boeri, and S.Cazes. Employment protection and labour market adjustment in OECD countries: Evolving institutions and variable enforcement. ILO Employment and Training Papers, No.48, ILO, Geneva 1999. 
Third, in some countries, compensation for unfair dismissal set by courts can deviate widely from the minimal set out in the legislation, since judges may account in their final decision for damages corresponding to past and expected future financial losses and psychological damage. ${ }^{21}$

Fourth, politisation of the judiciary system may introduce bias to decision making in courts. This can be due to ideological bias in the nomination of judges ${ }^{22}$ as well as due to administrative interventions from regional or local governments into independent judiciary decision making.

Fifth, corruption clearly distorts the role the judiciary and therefore can affect enforcement of the regulations. All these factors, except for the third, may play a role in Russia.

In most cases judiciary plays mainly a threatening role in the EPL enforcement. However, if the number of cases (per 1000 of population or employment) put before the court is quite significant, sanctions for the non-observance rules are unavoidable and biting, the likelihood in expecting a particular ruling is high, the duration of the trial is short, then we may expect that the enforcement regime will become more strict and robust.

\section{Data Issues}

In order to measure the regional variation in enforcement and to estimate its impact on regional labour market outcomes we have constructed a database that covers all years from 2000 through 2005. This provides us with the data panel containing around 480 yearregion observations. A more detailed description of the data used in the paper follows below.

\subsection{Data on Enforcement}

\subsubsection{Data on labour inspectorate activity}

The data is regularly collected by the Federal Labour Inspectorate and covers all the regions of the Russian Federation. We consider the total number of inspectors allocated across regions a key variable for measuring institutional capacity of this agency. The

\footnotetext{
${ }^{21}$ OECD Employment Outlook, 2004.

22 Berger H., M.Neugart. Labour Courts, Nomination Bias, and Unemployment in Germany. CESifo Working Paper No.1752, June 2006.
} 
intuition for this is straightforward since more inspectors are able to undertake more control missions and these missions can be more efficient if more time is allowed per mission. Fewer inspectors can undertake more missions only by reducing the time allocated per mission, and therefore by sacrificing enforcement efficiency. As Squire and SuthiwartNarueput (1997) point out, when inspection resources are limited, investigations tend to be initiated in response to complaints rather than being random. Additionally, there is also a higher probability of producing more in-desk reviews and fewer in-depths audits. ${ }^{23}$

In order to account for cross-regional variation in population, we divide the number of inspectors by employment in L\&M sized firms, by the total number of firms, and by the number of control missions. We put special emphasis on employment in L\&M size firms since that is the only segment of the economy that can pretend to be in fact monitored by the agency. Though formally the Labour Inspectorate authority extends far beyond the L\&M segment, its actual outreach there is almost negligible.

\subsubsection{Data on Judiciary}

Another set of data used in our study reflects performance of the judiciary. These data are routinely collected by the Judicial Department of the Supreme Court. The key variable here is the number of labour disputes annually filed to courts in a region. Within the total number of legal cases one can single out legal cases concerning wages and cases concerning employment and dismissals. We use data on the total number of labour disputes filed and the number of cases concerning unfair dismissals only. In order to account for variation in regions size we standardize (divide) these measures by L\&M sized employment, by the number of firms, etc.

\subsubsection{Perception of enforcement survey (PES) data}

The above presented data pretend to draw an objective picture using numbers of inspectors, of control missions, of orders issued, of legal cases filed, etc., as hard measures of the enforcement. We supplement these variables with additional indicators, which have to reflect how major labour market actors and the EPL enforcing agencies perceive actual stringency of enforcement and the degree of compliance. One can assume that, for example,

${ }^{23}$ Squire and Suthiwart-Narueput, The Impact of Labor Market Regulations World Bank Econ Rev.1997; 11: 119-143, p.127 
almost full compliance is associated with enforcement such as it is generally considered stringent by labour market actors, though the number of court appeals is low. This may also hold true vice versa.

For collecting subjective information, we conducted a special survey covering all regions of the Russian Federation. ${ }^{24}$ The special questionnaire focused on the EPL enforcement was sent to top officers in all regional staff-quarters of the Labour Inspectorate and the Employment Service, to regional representatives of the major $\mathrm{TU}$ federation (FNPR), and to regional representatives of the major employers' association (RSPP). Judges from regional and local courts dealing with labour disputes were surveyed in Moscow during their special educational (training) visits. For each agency, we designed a specialized questionnaire that combined a general (common to all agencies mentioned above) part and an agency-specific block. The questionnaire contained various questions about the degree of EPL observance in the region in general and about particular EPL dimensions.

Altogether we collected about 400 completed questionnaires covering all Russian regions. The major outreach problem in surveying that we encountered was with the trade unions federation and the employers associations. Their actual representation in most of the regions appeared to be limited and in some regions just nobody was ready to speak on the behalf of the organizations. However, this could be considered an additional indication for low enforcement capacity in some regions.

\subsection{Data on Labour Market Outcomes}

Here we rely on the annual labour market statistics routinely provided by the Rosstat. We use such variables as employment rate (total, female, and youth), unemployment rate (total, female, and youth). ${ }^{25} \mathrm{We}$ use female and youth employment/unemployment rates since these measures are considered more sensitive to labour market conditions compared to those for prime-age men.

\section{Main Hypotheses and Empirical Strategy}

\footnotetext{
${ }^{24}$ The survey was conducted in late 2006-early 2007. We acknowledge the assistance in data collection from N.Vishnevskaya.

${ }^{25}$ Since most of these variables are routinely measured using the LFS or administrative statistics data, we do not go into additional details here.
} 
Our empirical strategy is organized around two interconnected "Saltykov-Tchedrin hypotheses" that can be derived from his famous phrase presented in the epigraph to this paper. As we have already shown, the Russian EPL is one of the most stringent in the world, if formally measured. The gap between the formal stringency of legislation and its actual observance tends to be larger when laws are stricter and enforcement is weaker. Such gap, if it looms large, makes the actual regulations less certain and more varying across space and over time. But higher variation in the regulative regime is likely to translate into higher variation in market outcomes.

Hypothesis H1 assumes that the EPL enforcement is not complete and significantly varies across regions. Whatever enforcement measures we consider, they will show significant interregional variation. In practice, this means that the actual regime of regulation varies within a wide range: from very liberal in some regions to rather stringent in the others.

Hypothesis H2 tests labour market implications of the variable enforcement. According to $\mathrm{H} 2$, stricter enforcement of the stringent legislation is expected to correlate negatively with regional labour market performance. This may lead to the fact that in regions with stricter enforcement, employment rates tend to be significantly lower, while unemployment rates - higher, if other regional characteristics are controlled for.

We start with a general description of the enforcement regime in Russian regions using all sources of data available to us. Here we document the fact that variation is large and various enforcement measures are inter-correlated though they illuminate different dimensions of the enforcement.

Several econometric techniques were used to estimate the causal effects of EPL enforcement on labour market performance. They differ in how they account for differences across regions and changes through time. Another distinction concerns the way how they treat endogeneity problem.

We start with estimating impacts of enforcement applying the OLS estimation on the data pooled over the period 2000-2005. We estimate the set of relationships for various labour market outcomes based on the following equation:

$$
Y_{i t}=\alpha+\beta E_{i t}+\gamma X_{i t}+\phi_{t}+\varepsilon_{i t},
$$

where $\boldsymbol{Y}_{i t}$ refers to a specific labour market outcome in the $i$ region and the moment $t, \boldsymbol{E}_{i t}$ is some measure of EPL enforcement, $\boldsymbol{X}_{i t}$ is a vector of exogenous regional characteristics, $\boldsymbol{\phi}_{t}$ 's are yearly dummies, $\alpha, \beta, \gamma$ are coefficients. Finally, $\varepsilon_{i t}$ is an idiosyncratic iid error term. 
Concerning the exact specification of the models, we use six indicators of labour market performance as dependent variables. Two indicators refer to general situation at the labour market and those are overall employment and unemployment rates. Other indicators female and youth employment rates, female and youth unemployment rates - concentrate on specific segments of the labour force, which are considered mostly vulnerable to policy interventions. A priori we expect $\beta$ 's to be negative when Y's are employment rates and positive in case of unemployment outcomes.

In all equations, on the right hand we control for per capita Gross Regional Product, or GRP, taken as natural logarithm, GRP growth rate, and demographic variables (the proportion of urban population, the proportions of females and young people aged 15-29; fertility rates). We also include a dummy for Moscow and St-Petersburg, dummies for macro-regions (federal districts), dummies for autonomous republics and interactions between regional dummies and dummies for autonomous republics.

OLS fully accounts for cross-region variation but assumes that observations for each region are independent over time. Thus, it ignores potential autocorrelation and may produce inconsistent estimates if region-specific effects are present. These region-specific effects may be generated by political factors, specific policies of local administrations, cultural and historical traditions of law observance and enforcement, etc. We correct the OLS estimates by fitting fixed and random effects models designed to deal with panel data.

Each of the two panel data approaches has relative advantages and drawbacks. Fixedeffects (FE) estimates exploit only the within dimension of data, i.e. changes within regions, and leaves unused information about differences across regions. This may be impractical with the data we have since the panel is short and time-series variation in enforcement within regions is only moderate. Moreover, fixed effects estimates are generally more sensitive to measurement errors. Our explanatory variables are highly autocorrelated, and applying fixed-effects can remove true variation leaving mainly variation in measurement errors. Random-effects (RE) estimation combines the information from the between and within dimensions of the data in an efficient way and explains a larger share of variation in the data. It treats region-specific effects not captured by the explanatory variables included in equation as randomly distributed across regions. However, the FE estimation method should be preferred if there is a correlation between control variables and the unobserved heterogeneity in region-specific effects. For example, the pressure for the EPL enforcement 
may be correlated with the unobserved balance of political forces in a region. We report FE estimates but since within variation in the enforcements measures is low we treat RE model as our basic specification.

Using various estimation procedures will allow assessing the robustness of the estimated effects and thus will protect us from bias associated with using just one estimator. Having various estimates we may compare whether different methodologies provide similar results and if so, we get an additional robustness check. Doing so, we follow methodological suggestions based on studies of the impact of EPL strictness on labour market outcomes. ${ }^{26}$

\section{How Does the EPL Enforcement Vary Across Regions? Descriptive Analysis}

All major statistical measures of the EPL enforcement are presented in Table A2 (in the Appendix). They unambiguously indicate the existence of significant variation in the EPL enforcement efforts across Russian regions. We will discuss this issue in the next part of this section.

\section{Coverage}

Various segments of employment are exposed to the EPL to varying degrees. As it usually happens, small firms are partially or fully exempt from the standard EPL norms. ${ }^{27}$ Those hired by individual entrepreneurs or by other private citizens are exempt de-facto from these regulations as all self-employed are. In Russia, only those working for the L\&M size firms are subjected to the EPL. This makes the proportion of covered employees in the total employment an indirect indicator of the efficient EPL coverage. While the country mean equals to $58 \%$, this measure varies across regions from $40 \%$ to $74 \%$. As Fig.A2 suggests, the share of the L\&M size employment has been shrinking permanently in all regions over time, while the distribution has become more skewed to the left. At the same time, the interregional variation has been remaining significant and impressive. This means that the EPL-exempt employment can reach $60 \%$ of the total in some regions, hinting at strong labour market segmentation.

\footnotetext{
${ }^{26}$ OECD Employment Outlook, 2004, p.78.

27 Tito Boeri, Juan F. Jimeno. The effects of employment protection: Learning from variable enforcement, European Economic Review 49 (2005) 2057-2077.
} 
Activity of the Labour Inspectorate

All major indicators based on the Labour Inspectorate statistics show remarkable variation across regions in exposure of firms to inspections.

The key indicator in this family of measures is the density of inspectors, calculated as the number of inspectors standardized per 100 thousands of employees in large and medium sized firms. The measure varies from 3,0 in Moscow (followed up by other relatively well developed regions) to 25,0 in the ethnic Republic of Ingushetia or 13-20 in other remote or scarcely populated underdeveloped regions. The density of inspectors in the latter group of the regions exceeded the country average by 3-5 times and the Moscow level by 7-8 times higher, making firms much more exposed to the regulatory pressure.

In the Moscow City, one inspector was in charge of monitoring about 6 thousands firms (or organizations) during the year; in S-Petersburg the corresponding responsibility was 3 thousands firms. Obviously, such high load per inspector makes probability for a firm in either region to be inspected very low. The difference emerged from higher density of inspectors as well as from lower density of firms in low populated and remote regions. Low population density (small population scattered across small villages on large territory) may need more inspection offices and therefore more inspectors. However, this can be true only in some regions (to the East from the Urals).

Efficiency of the regional LI offices can be measured as the number of inspections (control missions) conducted during the year. It depends on the density of inspectors, since more inspectors per given population of firms or employees can initiate more missions. However, it depends also on the propensity of the LI to intervene in the situation, since additional extraordinary or irregular missions may emerge as local initiative. The latter makes this variable partially endogenous to the regional/local labour market situation. In 2000-2005, in the least inspected (controlled) regions there were on average 2.0-2.2 control missions per 1000 employees. In the most frequently inspected regions, there were 15.7-18.6 missions per 1000 workers, or 8-9 times more (see Table A2). Over the year, on average labour inspectors managed to inspect 12 firms of 1000 in Moscow, in S-Petersburg this number was also at low 23. In contrast, in the Kursk Oblast 460 firms of 1000 were checked, in the Chukotka region - 350, in Buryatia - 260. This meant that up to half of all firms came to the test of the EPL observance. 
The rate of detected EPL violations (calculated as the number of detected violations divided by the total employment) is one of the most evident measures of the enforcement. Its maximum value exceeds the minimum by 5 times! In general, it is positively correlated to the density of inspectors.

When examining interaction between the Labour Inspectorate and judiciary, we also observe high variation. In 2005, the LI in 35 of 79 regions did not file any case to the judiciary. However, in some regions the number of court appeals was quite high, and the Southern regions were especially salient in this respect. The Krasnodar Kray took the lead with 69 cases filed per 100 thnd employees. In these regions the number of court filings (standardized by employment) was 7-17 times higher that the country mean. Given that the maximum figures were not high in absolute numbers we can hypothesize that the LI had weak incentives in using judiciary. They could have preferred alternative options when dealing with violations of the labour law.

Judiciary authority (Courts)

Quantitative variables based on judiciary statistics tell basically the same story, showing significant inter-regional variation in enforcement of the labour regulations. This variation has also been high throughout the whole period of 2000-05.

The Far Eastern Magadan region with 200 legal cases (per 1,000 employees) filed to courts took the leading place. It was followed by a few other Northern and Far Eastern regions, where the corresponding values were in a range of 30 to 70 . On the opposite pole of the scale, we find the most urban and densely populated regions like Moscow, S-Petersburg, Moscow and Nizhny Novgorod oblasts situated in the European part of the country. Here, of every 1,000 employees, only 1 to 4 were involved in legal conflicts with their former or current employers in regional or local courts.

Largely the same distribution of regions emerges if we look at the legal cases on pay issues. The Northern and Far Eastern regions are among the most litigious regions, while the regions with the more developed and diversified economies are among the least litigious. Again, the gap between these two poles on the scale is remarkably large. The Magadan region shows as many as 160 litigations per 1,000 employees against just 0,8 litigations filed in Moscow. 
Interregional variation in the workers' propensity to use judiciary for disputing unjust dismissals is somewhat narrower but the general tendency is the same. The intensity of litigation varies from 3 cases filed per 1,000 employees to 0,2-0,3 cases and the distribution of regions is about the same as discussed above.

All the data that we are presenting here provides a very consistent and robust picture. The Northern and remote regions of the Far East with the least favourable climate conditions are among the most conflict prone. Here, the workers are endowed in accordance with the Labour Code with a generous package of additional social guaranties and benefits (the so called "Northern benefits package"), on the one hand. On the other, these local labour markets are weakly diversified and strongly isolated local monopsonies. Outside options for dismissed workers here are scanty, while migration costs in contrast emerge as prohibitively high. All this raises incredibly alternative costs of losing jobs to workers, therefore activating their "voice" and stimulating litigious activity. Expectation of winning a law suite supports this strategy. On the contrary, in regions with the more diversified labour demand a "voice" strategy becomes less beneficial compared to an "exit" strategy, and these simple costbenefit considerations may suppress or drive down propensity to litigate. In case of losing a job, a worker here can find a new one quickly and at low cost instead of being dragged into a lengthy and costly litigation.

\section{Survey evidence}

Our survey provides some additional evidence that the EPL observance being far from complete varies across regions within the wide band.

As the Table A3 undoubtedly suggests, the proportion of those surveyed believing that the EPL observance does not pose any problem is very small. This opinion is shared by just $3 \%$ of the judges, $8 \%$ of the employers' representatives and by $3 \%$ of the TU regional leaders that were surveyed. None of the surveyed labour inspectors or the employment service top officers underlined this position. On the contrary, $10-37 \%$ of our respondents consider non-observance an acute problem. If measured on a 7-point scale with the maximum given to the complete observance, regions vary from 2,3 to 5,0 points.

The Fig.A1 presents average scores to the EPL observance across various EPL segments assigned by our respondents if they use the 7-point scale. As we can easily see, most of the averages are under a value of 4 points, while the employers only assign just a 
little more than that. Table A4 extends the picture differentiating these scores by segments of the EPL. Our respondents assessed the issues of enforcement of the rules that regulate hirings, separations, and pay as the most problematic. The preparation of collective agreements and provision of the TU rights appeared to be the least problematic and the most observed. However, the table confirms the basic conclusion that the EPL enforcement seems to be quite problematic.

The level of the EPL observance varies within regions as well. Firms with some political connections and administrative support may feel much less constrained in applying the rules. An additional factor affecting the law observance is the firm size, since small firms are less prone to follow the rules while their monitoring is much more complex and costly. We asked our respondents whether "there are differences between firms in the EPL observance in their region" According to the Table A5, significant intraregional differences in the EPL observance are recognized by $36-59 \%$ of our respondents, while most of the other respondents accept that there are differences, though insignificant. Interestingly, speakers for employers are most prone to recognize selective observance while judges are the least prone. The proportion of those believing that there are no such differences is well under $10 \%$ of the total sample.

All the evidence mentioned above tends to confirm the key point that EPL observance in Russian regions is incomplete, selective, and varying. This concerns particular segments of the labour law relatively more than others. Some firms are also more exposed to enforcement than others. This seems to turn legislative framework into a kind of mosaic or patchwork. To explore how variation in observance and enforcement across regions may affect labour market performance, we turn to the next paragraph.

Why is the enforcement of labor laws in Russia so poor? This is a big and interesting issue clearly deserving a special in-depth study but it goes far beyond the scope of this paper. To be short here, we can just list a mix of different economic as well as politico-economic factors, destroying compliance and feeding into law avoidance.

Offering very strong "paper protection", these laws are very costly in monitoring and enforcement. This makes them not enforceable in practice. Additionally, we can add factors such as high levels of corruption, lack of tradition for following the rule of law, lack or weakness of institutions enforcing labor contracts, weak bargaining power of workers 
(especially in times of high and rising unemployment), cheap alternative options for workers and employers.

\section{Estimating the Impact of Enforcement}

Simple charts that plot some EPL enforcement measures against major labour market outcomes visualize associations we are looking for. Fig A5 shows correlation $(r=0,46$, statistically significant at 5\% level) between institutional capacity of the LI (the number of inspectors per L\&M employment) and the judiciary activity (the number of labour disputes filed to courts also per L\&M employment) in Russian regions, suggesting that both enforcements work in the same direction, potentially reinforcing each other.

Figures A6 and A7 illustrate some relationships between indicators of enforcement and unemployment. The institutional capacity of the labour inspectorate (measured as number of inspectors per employment in large and medium sized firms) is positively associated with unemployment and is negatively associated with employment. The same associations hold true for judicial enforcement measured as the number of legal cases on labour disputes filed to regional courts, and labour market indicators. The association becomes stronger if we consider only legal cases on unfair dismissals. More active judiciary involvement in labour market regulation is likely to be associated with lower employment and higher unemployment. Both measures of the enforcement are negatively correlated with regional economic development.

However, simple correlations present a very raw picture and say nothing about the direction of causuality. Having said that we are moving to the regression analysis.

According to our second hypothesis, stricter enforcement is expected to drive employment rates down. If this holds true, then coefficients for enforcement proxies in the regressions are expected to be negative and statistically significant. Tables A6-A8 present the point estimates drawn from all tested specifications. We consequently consider three different employment measures (for the total population, for women, for youth - 15-29 years old). The male prime-age employment is usually quite robust and low sensitive to marginal changes in regulations. Over the whole transition period in Russia, this e/p ratio has changed very little. Since women and youth positions in the labour market are more volatile and sensitive to shocks, we may expect that the coefficients of enforcement variables in these specifications display higher statistical significance than in equations with overall employment. 
For general employment rate the number of inspectors in all specifications is statistically significant and has the expected (negative) sign. All point estimates in OLS, FE, and RE models are almost identical for each labour market indicator. This suggests that stricter enforcement tends to suppress employment. We estimate that, on average, when the number of inspectors per $100000 \mathrm{~L} \& \mathrm{M}$ employment in the region increases by 1 , the $\mathrm{e} / \mathrm{p}$ ratio goes down by 0.25 percentage points. In our sample, the average number of inspectors per 100000 L\&M employment in the region is 11.5 and the e/p ratio is 58.3. Based on these numbers the computed elasticity of the general employment rate with respect to the number of inspectors is of -0.05 . For females, the relevant elasticity is a bit lower and lies in the range of - $0.040-0.045$. On the contrary, for the young we find the elasticity two times higher than that. Our estimates of elasticity of the youth employment rate with respect to the number of inspectors fall in the range between -0.08 and -0.09 . Thus, larger institutional capacity of labor inspectorates has stronger negative effects on new entrants to the labour market than on incumbent labour force. However, it is important to note that other incumbents do not seem to benefit from it as well.

The variables that are based on the number of violations detected by the LI and the number of control missions used as enforcement proxies tell a similar story; though in RE and FE specifications their coefficients are mostly statistically insignificant. Again, for young people we find larger coefficients and more of them are in fact significant. However, generally these measures do not provide strong support for adverse consequences of stricter EPL enforcement. Much of statistical significance vanishes when we account for regionspecific effects.

The last three lines in tables A6-A8 relate to the judiciary enforcement. Here, the evidence is more mixed. The coefficients for our measures of the judiciary enforcement are mostly significant and have expected negative signs in OLS regressions. In RE and FE models this holds only for the total number of labour disputes filed to courts. Two other variables - the number of judges and the number of disputes on unfair dismissal - enter with insignificant coefficients or even have significantly positive coefficients in the FE estimation. An elasticity of the general employment rate with respect to the number of labour disputes filed to courts is not larger than -0.02 (if computed from the OLS estimates and even lower for RE and FE). For females and youth, the relevant elasticities are marginally higher and do not exceed -0.025 . Thus, the effect of judiciary enforcement on employment 
rates, if any, is small and less important than the impact of labour inspectorates' activities. The limited court capacity may be one of the reasons.

Let us turn now to another basic indicator of the labour market performance - the unemployment rate. Our main expectation here is to see statistically significant and positive coefficients for all enforcement variables. If $\mathrm{H} 2$ holds true, then stricter enforcement should bring higher unemployment. Again, the motivation is straightforward since higher labour costs associated with enforcement of the strict EPL constrain labour demand and keep people out of jobs, other things being equal. Tables A9-A11 present our abbreviated results.

All but one coefficient in the OLS estimation are positive and significant while RE and especially FE produce less significant estimates. Again, we have unexpected negative signs for the coefficients of number of disputes on unfair dismissals in the FE model. OLS coefficients suggest larger effects of stricter enforcement on unemployment than other estimation techniques. Therefore, calculating elasticities we used RE estimates to compute the lower bound and OLS estimates to compute the upper bound.

The number of inspectors performs better than other proxies of enforcement by labour inspectorates. It has significant coefficients in the RE model for all our measures of labour market situation. Elasticities of unemployment rate with respect to the number inspectors are fairly large. For overall unemployment rate our estimates range from 0.31 to 0.43. For females the spread in estimates is smaller, but the average tends to be higher as an elasticity is between 0.38 and 0.42 . Young people are affected the most by stricter enforcement - an elasticity is equal to $0.50-0.64$. However, other measures of the EPL enforcement by labour inspectorates give inconclusive results. The coefficients of the number of control missions and the number of violations detected are insignificant in most $\mathrm{RE}$ and in all FE specifications.

Judicial enforcement of the EPL seems to have stronger effect on the unemployment rates than on the employment rates. The number of judges is significant for all three unemployment rates in OLS and RE specifications. We computed elasticities of the unemployment rates with respect to the number of labour disputes filed to courts. The estimates are lower for the general unemployment rate $-0.05-0.21$, followed by the youth unemployment rate $-0.11-0.23$. Female unemployment rates are most sensitive to the strictness of judicial enforcement and show elasticities with values between 0.14 and 0.27 . 
Combining the estimates, we can cautiously say that despite multiple measurement and estimation problems, econometric evidence available to us so far suggests that there are no reasons to reject Saltykov-Tchedrin's hypothesis. Comparing female and youth segments with the labour market average we can conclude that young workers disproportionally bear the burden of employment protection. This can be explained by the fact that firms are more aware of hiring young people and as labour market outsiders young suffer most from overly strict regulations. This means that more interventionist LI policy in this area tends to affect young people first and foremost.

All three estimators (OLS, FE and RE) assume that enforcement indicators are uncorrelated with the error term $\left(\varepsilon_{i t}\right)$ or, in other words, that they are exogenous to labour market outcomes. If such assumption does not hold then panel estimates would also be inconsistent. So, as the next step, we apply the instrument variable estimation to some of our panel data models. Such correlations with the error term can appear if labour markets outcomes have influence on enforcement variables. For example, regional authorities in high unemployment regions may bear additional pressure upon labour inspectorates requiring for more control missions in order to preserve existing jobs. This in turn may increase firing costs for employers and dampen new hirings leading to further worsening of the situation at the labour market. This argumentation suggests that we are likely to have a positive bias for the indicators of the LI activities.

Concerning judges, we have already mentioned the paper by Ichino et al (2003), which provides empirical evidence that conditions at local labour markets can bias judges' decisions in favour of workers and encourage dismissed workers in high unemployment regions to go to courts. In this case the estimate of the enforcement effect can be positively biased. If courts favoured firms in such situations than dismissed workers would be discouraged to file their cases to the courts and the bias will go in the opposite direction. Another set of arguments can be offered in favour of negative bias relating workers' propensity to apply for judicial protection to the availability of outside options. In a tight labour market, outside conditions are favourable to workers and workers can exploit an exit option at relatively low cost. On the contrary, higher unemployment reduces availability of outside options and thus decreases relative costs of using judiciary protection. Thus, in case of courts the direction of the bias cannot be determined theoretically. 
We do believe that the number of inspectors and judges are exogenous to labour market conditions. The number of inspectors is allocated across regions by the central office according to uniform norms, which are based on the population size in the region, but not on local labour market conditions. This allows us to argue that the regional density of inspectors network is not conditional upon the level of employment or unemployment. However, actual performance of regionally located inspectors is likely to be endogenous to the local labour market outcomes. So, we cannot exclude endogeneity in case of the number of control missions and violations detected. These results should be treated cautiously and are potentially subject to endogeneity bias.

Similarly, the number of judges is set at the federal level (accounting mostly for population size) and certainly does not account for local labour market conditions. In Russia special labour courts are non-existent and labour disputes are considered in courts of general jurisdiction, which mostly deal with criminal and administrative cases. But following Ichino's arguments we suspect endogeneity in the total number of labour disputes filed and the number of cases concerning unfair dismissals. Since workers' propensity to apply for judicial protection is negatively correlated with availability of outside options, we may expect here an endogeneity bias. In a tight labour market, outside conditions are favourable to workers and workers can exploit an exit option at relatively low cost. On the contrary, higher unemployment reduces availability of outside options and thus decreases relative costs of using judiciary protection.

We made experiments with various instruments (the homocide rate, the crime rate, the industrial injury rate, the density of motorways, the distance from Moscow, the share of federal and local government employment in total employment, a dummy for the New Labor Code, proxies for the state of democracy in the regions) and their interactions. Unfortunately, validity of our instruments was not supported by statistical tests. Thus, further research is needed on looking for valid instruments for activities of enforcement institutions.

\section{Conclusion}

For many Russians, Saltykov-Tchedrin's statement presents not a hypothesis but a self-evident axiom. However, whether it is true or not has never been tested with the use of empirical data. If this is still in fact true, there may many important policy implications related to design and enforcement of legislation. We believe that laws governing job 
protection are a good example of how to test Saltykov-Tchedrin's idea. Adoption of this legislation and its enforcement lay in different dimensions and are governed by different political and economic logics. Large and widening gap may have multiple consequences. On the one hand, it destroys the rule of law and feeds into lawlessness and corruption; on the other, it partially compensates negative economic and social outcomes from poorly designed regulations.

Since the early 1990s, economists in many countries have been paying much attention to the interaction between EPL and operation of the labour market. This interest has brought a wide stream of literature on the impact of job protection regulations on labour market outcomes. However, empirical evidence on these effects remains incomplete or ambiguous. A few reasons matter here. First, transition economies are left outside existing studies. Second, most of these studies are based on cross-country data containing little variation in EPL regimes. Third, in most cases incomplete and variable enforcement is not taken into account. Researchers usually equate formal legislative norms to actual law compliance. This happens partially due to the fact that the degree of actual enforcement/compliance is hard to measure, partially due to the fact that in the OECD economies the gap between regulations and compliance is relatively small and can be ignored. However, transition economies present a completely different case since weak institutions cannot enforce EPL rules, though these rules are quite strict. If in practice the EPL works as a paper protection only, then it can hardly have any impact on the labour market activity.

Our study tries to overcome these limitations. This is the first try to study this issue using such large and diverse transition country as Russia. Second, it uses not national but sub-national data. Third, we account for EPL enforcement variation what allows for a better capture of the actual EPL effects on regional labour markets.

Russia has inherited very strict EPL from her socialist past, and this EPL has undergone only marginal adjustments. However, state institutions remain weak, and their interventions are inefficient and non-random. The Russian labour legislation is under the federal jurisdiction and is universal across the country, but its enforcement is always regional or sub-regional. Social, economic and political diversity of regions generate significant heterogeneity in EPL enforcement.

These considerations are translated into two key hypotheses. First, we expect to see significant variation in the EPL enforcement across regions. Second, we assume that more 
strict control over the EPL compliance is likely to have suppressive (negative) effects on major labour market outcomes (employment, unemployment, vacancies). For testing these assumptions we use data related to the Labour Inspectorate activity and to the judiciary activity. Neither of the hypotheses can be rejected given the available data.

We have revealed significant variation in the EPL enforcement across Russian regions. This is true regardless of which of the EPL enforcement variables we have considered. Some regions tend to cluster closer to one pole of the scale and some others appear to be closer to the opposite pole. The place a region occupies at this scale is explained by various factors: by specific features of these regional economies, by the institutional capacity of regional courts and judiciary, by political bias of regional authorities. As it has appeared, even within the same regions the LI and judiciary could react differently, therefore increasing total variation in actual enforcement/compliance.

We have also shown some general patterns concerning the variation in EPL enforcement across Russian regions. Violations of employment legislation were most frequent in two different groups of regions. First, these are regions located in the North and Far East; second, some ethnic autonomies. The most affluent regions with more diversified economies and with dynamic labour markets are outsiders in this respect, showing relatively few violations of the labour legislation. This may suggest that the demand for enforcement is lower in these regions, since enforcement capacities may be even stronger here.

Our analysis also suggests that interregional differences in the EPL enforcement have statistically significant impact on regional economies and labour markets. We regress regional labour market performance indicators on regional enforcement variables, controlling for other regional characteristics. For most of the estimated equations (though not for all), coefficients are statistically significant and have the expected sign. In order to account for unobserved heterogeneity, we apply FE and RE panel data techniques. This adds empirical arguments to the point that the stringent EPL if efficiently enforced, tend to suppress employment and stimulate unemployment. Women and young people are among those who hit first and foremost. Therefore, the strict EPL targeted on protection of the most vulnerable groups in the labour market is likely to act precisely against these groups.

From the policy implications point of view, our analysis warns against straightforward strengthening of enforcement, if the formal EPL is very stringent. This can bring the outcome that is opposite to what politicians actually want. Since many legal norms 
in Russia are too burdensome and costly, following them threatens to suppress labour demand. Employers may choose to exit the market or to reduce their participation in labour market instead of fully complying.

In order to raise the general level of the EPL compliance, the EPL should become easier, more transparent, and less costly. Its rationalization even under weak enforcement institutions could weaken incentives to avoid laws and formal rules, limit selectivity of the enforcement, and compress variation in law compliance. This would be a significant contribution to creating the institutional environment in which Saltykov-Tchedrin's hypothesis could be rejected. 
Appendix: Tables and Graphs

Table A1. Normative Firing Costs in Russia and Some OECD Countries, number of months and monthly wages

\begin{tabular}{|c|c|c|c|c|c|c|}
\hline & \multicolumn{3}{|c|}{ Advance notice (months) } & \multicolumn{3}{|c|}{$\begin{array}{c}\text { Severance pay (months of av } \\
\text { wage) }\end{array}$} \\
\hline & \multicolumn{3}{|c|}{ Tenure } & \multicolumn{3}{|c|}{ Tenure } \\
\hline & 9 months & 4 years & 20 years & 9 months & 4 years & 20 years \\
\hline Russia & & $2 *$ & & \multicolumn{3}{|c|}{$\begin{array}{c}2-3 *(+3 \text { months for the } \\
\text { Northern and Far Eastern } \\
\text { Regions })\end{array}$} \\
\hline Sweden & 1 & 3 & 6 & 0 & 0 & 0 \\
\hline Finland & 1 & 2 & 6 & 0 & 0 & 0 \\
\hline Germany & 1 & 1 & 7 & 0 & 0 & 0 \\
\hline France & 1 & 2 & 2 & 0 & 0.4 & 2.7 \\
\hline Italy & 0.3 & 1.1 & 2.2 & 0.7 & 3.5 & 18 \\
\hline UK & 0.2 & 0.9 & 2.8 & 0 & 0.5 & 2.4 \\
\hline USA & 0 & 0 & 0 & 0 & 0 & 0 \\
\hline Czech Republic & 2 & 2.5 & 2.5 & 1 & 1 & 1 \\
\hline Hungary & 1 & 1.2 & 3 & 0 & 1 & 1 \\
\hline Poland & 2 & 3 & 3 & 0 & 0 & 0 \\
\hline
\end{tabular}

* - firing costs are constant over the tenure

Sources: the RF Labour Code; OECD Employment Outlook, Paris, 2003. 
Table A2. Enforcement in Russian Regions: Descriptive Statistics, 2005

\begin{tabular}{|c|c|c|c|c|c|c|c|c|}
\hline & $\mathrm{N}$ & mean & se(mean) & sd & p50 & $\min$ & $\max$ & $\mathrm{cv}$ \\
\hline Proportion of L\&M employment & 79 & 57.8 & 0.7 & 6.5 & 57.9 & 37.8 & 72.2 & $11.2 \%$ \\
\hline \multicolumn{9}{|l|}{ Labour Inspectorate } \\
\hline $\mathrm{N}$ of firms per 1 inspector & 80 & 1043.2 & 105.4 & 943.1 & 900.5 & 318.8 & 8089.5 & $90.4 \%$ \\
\hline $\begin{array}{l}\mathrm{N} \text { of inspectors per } 100,000 \mathrm{~L} \& \mathrm{M} \\
\text { employees }\end{array}$ & 79 & 113.6 & 6.9 & 61.5 & 100.5 & 51.4 & 483.4 & $54.1 \%$ \\
\hline $\mathrm{N}$ of control missions per 1 inspector & 80 & 72.4 & 2.3 & 20.7 & 70.0 & 30.5 & 138.5 & $28.6 \%$ \\
\hline $\mathrm{N}$ of control missions per 1 firm & 80 & 0.090 & 0.006 & 0.052 & 0.083 & 0.010 & 0.362 & $57.5 \%$ \\
\hline $\begin{array}{l}\mathrm{N} \text { of control missions per } 1000 \mathrm{empl} \\
(\mathrm{L} \& \mathrm{M})\end{array}$ & 79 & 8.08 & 0.46 & 4.10 & 7.05 & 3.16 & 24.71 & $50.7 \%$ \\
\hline $\mathrm{N}$ of law violations per 1 inspector & 80 & 521.6 & 23.5 & 210.1 & 507.8 & 170.2 & 1188.7 & $40.3 \%$ \\
\hline $\begin{array}{l}\mathrm{N} \text { of employees returned to jobs due to } \\
\text { LI intervention, per 100,000 L\&M } \\
\text { employees }\end{array}$ & 79 & 56.2 & 6.8 & 60.2 & 33.5 & 0.0 & 322.1 & $107.1 \%$ \\
\hline $\begin{array}{l}\text { Av } \mathrm{N} \text { of violations per } 1 \text { control mission } \\
\text { Courts }\end{array}$ & 80 & 7.3 & 0.3 & 2.6 & 6.9 & 1.6 & 16.2 & $34.8 \%$ \\
\hline $\begin{array}{l}\mathrm{N} \text { of legal cases on unjust dismissals by } \\
1,000 \mathrm{~L} \& \mathrm{M} \text { employees }\end{array}$ & 79 & 1.088 & 0.064 & 0.566 & 0.867 & 0.419 & 3.094 & $52.0 \%$ \\
\hline $\begin{array}{l}\text { Total } \mathrm{N} \text { of legal cases in courts per } 1,000 \\
\text { L\&M employees }\end{array}$ & 79 & 26.8 & 3.0 & 26.3 & 21.0 & 3.2 & 200.9 & $98.0 \%$ \\
\hline
\end{tabular}


Table A3. "How Serious is the Problem of the EPL Observance in Your Region?”, \%

\begin{tabular}{lccccc}
\hline & Judges & $\begin{array}{c}\text { Labour } \\
\text { Inspectors }\end{array}$ & RES & Employers & TU \\
\hline - very acute problem & 12 & 37 & 18 & 23 & 10 \\
- quite serious & 85 & 56 & 77 & 68 & 83 \\
problem & 3 & - & - & 8 & 2 \\
- almost unserious & & & & & \\
problem & & & & & \\
\hline
\end{tabular}

Table A4. To What Degree the Following Norms Are Observed? (Full Compliance = 7)

\begin{tabular}{|c|c|c|c|c|c|}
\hline & Judges & LI & ES & Employers & TU \\
\hline $\begin{array}{l}\text { Preparation and signing of } \\
\text { collective agreements }\end{array}$ & 4.5 & 4.7 & 4.1 & 4.6 & 4.3 \\
\hline $\begin{array}{l}\text { Hirings, signing up labour } \\
\text { contracts }\end{array}$ & 3.9 & 3.6 & 3.9 & 4.3 & 3.7 \\
\hline $\begin{array}{l}\text { Separations, cancellation of labour } \\
\text { contracts }\end{array}$ & 3.8 & 4.0 & 3.9 & 4.2 & 3.7 \\
\hline Use of short-term contracts & 4.3 & 4.0 & 3.9 & 3.5 & 3.9 \\
\hline \multicolumn{6}{|l|}{ Working time, incl over-time work } \\
\hline Pay & 4.0 & 3.4 & 3.7 & 4.2 & 3.6 \\
\hline Timing of pay & 4.2 & 4.5 & 4.3 & 4.4 & 4.3 \\
\hline $\begin{array}{l}\text { Social guaranties and benefits for } \\
\text { particular groups of workers }\end{array}$ & 4.1 & 4.4 & 3.8 & 4.1 & 4.0 \\
\hline TU rights & 4.4 & 4.9 & 4.1 & 4.5 & 4.4 \\
\hline
\end{tabular}

Table A5. Are There Differences Between Firms in the EPL Observance in Your Region?, \%

\begin{tabular}{lccccc}
\hline & Judges & LI & ES & Employers & TU \\
\hline Almost no differences & 9 & 3 & 4 & 11 & 7 \\
Insignificant differences & 55 & 40 & 46 & 29 & 46
\end{tabular}


Table A6. Regression coefficients, OLS, FE, and RE Estimates, Dep= employment rate

\begin{tabular}{|c|c|c|c|c|}
\hline \multicolumn{2}{|c|}{ Dep: employment rate (e/p ratio) } & OLS & $\mathrm{FE}$ & $\mathrm{RE}$ \\
\hline 1 & $\begin{array}{l}\text { LI: N of inspectors per } 100,000 \text { L\&M } \\
\text { employment }\end{array}$ & $-0.254 * * *$ & $-0.252 * * *$ & $-0.263 * * *$ \\
\hline 2 & $\begin{array}{l}\text { LI: N of violations detected per 1,000 L\&M } \\
\text { employees }\end{array}$ & $-0.021 * * *$ & -0.011 & -0.011 \\
\hline 3 & $\begin{array}{l}\text { LI: N of control missions per 1,000 L\&M } \\
\text { employees }\end{array}$ & $-0.193 * * *$ & -0.052 & $-0.094 *$ \\
\hline 4 & $\begin{array}{l}\text { Courts: } \mathrm{N} \text { of judges per 100,000 L\&M } \\
\text { employment }\end{array}$ & $-0.015 *$ & 0.028 & 0.003 \\
\hline 5 & $\begin{array}{l}\text { Courts: } \mathrm{N} \text { of all labour disputes filed per } 1,000 \\
\text { L\&M employees }\end{array}$ & $-0.056 * * *$ & $-0.019 * *$ & $-0.025 * * *$ \\
\hline 6 & $\begin{array}{l}\text { Courts: } \mathrm{N} \text { of disputes on unfair dismissals per } \\
1,000 \text { L\&M employees }\end{array}$ & $-2.248 * * *$ & 0.081 & -0.493 \\
\hline
\end{tabular}

Table A7. Regression coefficients, OLS, FE, and RE Estimates, Dep = female employment rate

\begin{tabular}{|c|c|c|c|c|}
\hline \multicolumn{2}{|c|}{ Dep: female employment rate (e/p ratio) } & OLS & FE & RE \\
\hline 1 & $\begin{array}{l}\text { LI: } \mathrm{N} \text { of inspectors per 100,000 L\&M } \\
\text { employment }\end{array}$ & $-0.198 * * *$ & $-0.209 * * *$ & $-0.213 * * *$ \\
\hline 2 & $\begin{array}{l}\text { LI: N of violations detected per 1,000 L\&M } \\
\text { employees }\end{array}$ & -0.005 & 0.007 & 0.007 \\
\hline 3 & $\begin{array}{l}\text { LI: N of control missions per 1,000 L\&M } \\
\text { employees }\end{array}$ & $-0.104 * *$ & 0.071 & 0.020 \\
\hline 4 & $\begin{array}{l}\text { Courts: } \mathrm{N} \text { of judges per } 100,000 \mathrm{~L} \& \mathrm{M} \\
\text { employment }\end{array}$ & -0.003 & -0.026 & -0.018 \\
\hline 5 & $\begin{array}{l}\text { Courts: } \mathrm{N} \text { of all labour disputes filed per } 1,000 \\
\text { L\&M employees }\end{array}$ & $-0.063 * * *$ & $-0.044 * * *$ & $-0.048 * * *$ \\
\hline 6 & $\begin{array}{l}\text { Courts: } \mathrm{N} \text { of disputes on unfair dismissals per } \\
\text { 1,000 L\&M employees }\end{array}$ & $-1.603 * * *$ & $1.295^{* * *}$ & 0.528 \\
\hline
\end{tabular}

Table A8. Regression coefficients, OLS, FE, and RE Estimates, Dep = youth (aged 1529) employment rate

\begin{tabular}{|c|l|c|c|c|}
\hline \multicolumn{2}{|c|}{ Dep: youth employment rate (e/p ratio) } & OLS & FE & RE \\
\hline 1 & $\begin{array}{l}\text { LI: N of inspectors per 100,000 L\&M } \\
\text { employment }\end{array}$ & $-0.357^{* * *}$ & $-0.334^{* * * *}$ & $-0.343^{* * *}$ \\
\hline 2 & $\begin{array}{l}\text { LI: N of violations detected per 1,000 L\&M } \\
\text { employees }\end{array}$ & $-0.056^{* * *}$ & -0.011 & $-0.024 * *$ \\
\hline 3 & $\begin{array}{l}\text { LI: N of control missions per 1,000 L\&M } \\
\text { employees }\end{array}$ & $-0.371^{* * *}$ & -0.130 & $-0.204 * * *$ \\
\hline 4 & $\begin{array}{l}\text { Courts: N of judges per 100,000 L\&M } \\
\text { employment }\end{array}$ & $-0.032^{* * *}$ & $0.047 * *$ & 0.009 \\
\hline 5 & $\begin{array}{l}\text { Courts: N of all labour disputes filed per 1,000 } \\
\text { L\&M employees }\end{array}$ & $-0.056^{* * *}$ & $-0.047 * * *$ & $-0.046^{* * *}$ \\
\hline
\end{tabular}


6 Courts: $\mathrm{N}$ of disputes on unfair dismissals per 1,000 L\&M employees 
Table A9. Regression coefficients, OLS, FE, and RE Estimates, Dep= unemployment rate

\begin{tabular}{|c|c|c|c|c|}
\hline \multicolumn{2}{|c|}{ Dep: unemployment rate } & OLS & $\mathrm{FE}$ & $\mathrm{RE}$ \\
\hline 1 & $\begin{array}{l}\text { LI: N of inspectors per 100,000 L\&M } \\
\text { employment }\end{array}$ & $0.382 * * *$ & -0.040 & $0.274 * * *$ \\
\hline 2 & $\begin{array}{l}\text { LI: N of violations detected per 1,000 L\&M } \\
\text { employees }\end{array}$ & $0.024 * * *$ & -0.007 & -0.006 \\
\hline 3 & $\begin{array}{l}\text { LI: } \mathrm{N} \text { of control missions per } 1,000 \mathrm{~L} \& \mathrm{M} \\
\text { employees }\end{array}$ & $0.322 * * *$ & -0.006 & $0.110 * *$ \\
\hline 4 & $\begin{array}{l}\text { Courts: } \mathrm{N} \text { of judges per } 100,000 \mathrm{~L} \& \mathrm{M} \\
\text { employment }\end{array}$ & $0.053 * * *$ & -0.023 & $0.028 * *$ \\
\hline 5 & $\begin{array}{l}\text { Courts: } \mathrm{N} \text { of all labour disputes filed per } 1,000 \\
\text { L\&M employees }\end{array}$ & $0.099 * * *$ & 0.000 & $0.023 * *$ \\
\hline 6 & $\begin{array}{l}\text { Courts: } \mathrm{N} \text { of disputes on unfair dismissals per } \\
1,000 \text { L\&M employees }\end{array}$ & $3.709 * * *$ & $-0.589 *$ & $1.017 * * *$ \\
\hline
\end{tabular}

Table A10. Regression coefficients, OLS, FE, and RE Estimates, Dep = female unemployment rate

\begin{tabular}{|c|c|c|c|c|}
\hline \multicolumn{2}{|c|}{ Dep: female unemployment rate } & OLS & FE & $\mathrm{RE}$ \\
\hline 1 & $\begin{array}{l}\text { LI: N of inspectors per 100,000 L\&M } \\
\text { employment }\end{array}$ & $0.351 * * *$ & 0.005 & $0.323 * * *$ \\
\hline 2 & $\begin{array}{l}\text { LI: N of violations detected per 1,000 L\&M } \\
\text { employees }\end{array}$ & 0.012 & -0.018 & $-0.019 *$ \\
\hline 3 & $\begin{array}{l}\text { LI: N of control missions per 1,000 L\&M } \\
\text { employees }\end{array}$ & $0.263 * * *$ & -0.126 & 0.074 \\
\hline 4 & $\begin{array}{l}\text { Courts: } \mathrm{N} \text { of judges per } 100,000 \mathrm{~L} \& \mathrm{M} \\
\text { employment }\end{array}$ & $0.053 * * *$ & 0.033 & $0.065 * * *$ \\
\hline 5 & $\begin{array}{l}\text { Courts: } N \text { of all labour disputes filed per } 1,000 \\
\text { L\&M employees }\end{array}$ & $0.124 * * *$ & $0.028 * *$ & $0.065^{* * *}$ \\
\hline 6 & $\begin{array}{l}\text { Courts: } \mathrm{N} \text { of disputes on unfair dismissals per } \\
1,000 \mathrm{~L} \& \mathrm{M} \text { employees }\end{array}$ & $3.272 * * *$ & $-2.502 * * *$ & 0.486 \\
\hline
\end{tabular}

Table A11. Regression coefficients, OLS, FE, and RE Estimates, Dep = youth (aged 1529) unemployment rate

\begin{tabular}{|c|c|c|c|c|}
\hline \multicolumn{2}{|r|}{ Dep: youth unemployment rate } & OLS & FE & RE \\
\hline 1 & $\begin{array}{l}\text { LI: } \mathrm{N} \text { of inspectors per 100,000 L\&M } \\
\text { employment }\end{array}$ & $0.538 * * *$ & 0.060 & $0.419 * * *$ \\
\hline 2 & $\begin{array}{l}\text { LI: N of violations detected per 1,000 L\&M } \\
\text { employees }\end{array}$ & $0.037 * * *$ & -0.015 & -0.010 \\
\hline 3 & $\begin{array}{l}\text { LI: N of control missions per 1,000 L\&M } \\
\text { employees }\end{array}$ & $0.462 * * *$ & -0.046 & 0.137 \\
\hline 4 & $\begin{array}{l}\text { Courts: } N \text { of judges per } 100,000 \mathrm{~L} \& \mathrm{M} \\
\text { employment }\end{array}$ & $0.074 * * *$ & -0.024 & $0.044 * *$ \\
\hline 5 & Courts: $\mathrm{N}$ of all labour disputes filed per 1,000 & $0.164 * * *$ & $0.054 * * *$ & $0.080 * * *$ \\
\hline
\end{tabular}




\begin{tabular}{|c|l|l|l|c|}
\hline & L\&M employees & & & \\
\hline 6 & $\begin{array}{l}\text { Courts: N of disputes on unfair dismissals per } \\
1,000 \text { L\&M employees }\end{array}$ & $4.752 * * *$ & $-2.544 * * *$ & 0.252 \\
\hline
\end{tabular}


Fig. A1. The degree of EPL Observance, 7-point scale, 1 - complete ignorance, 7 - complete observance

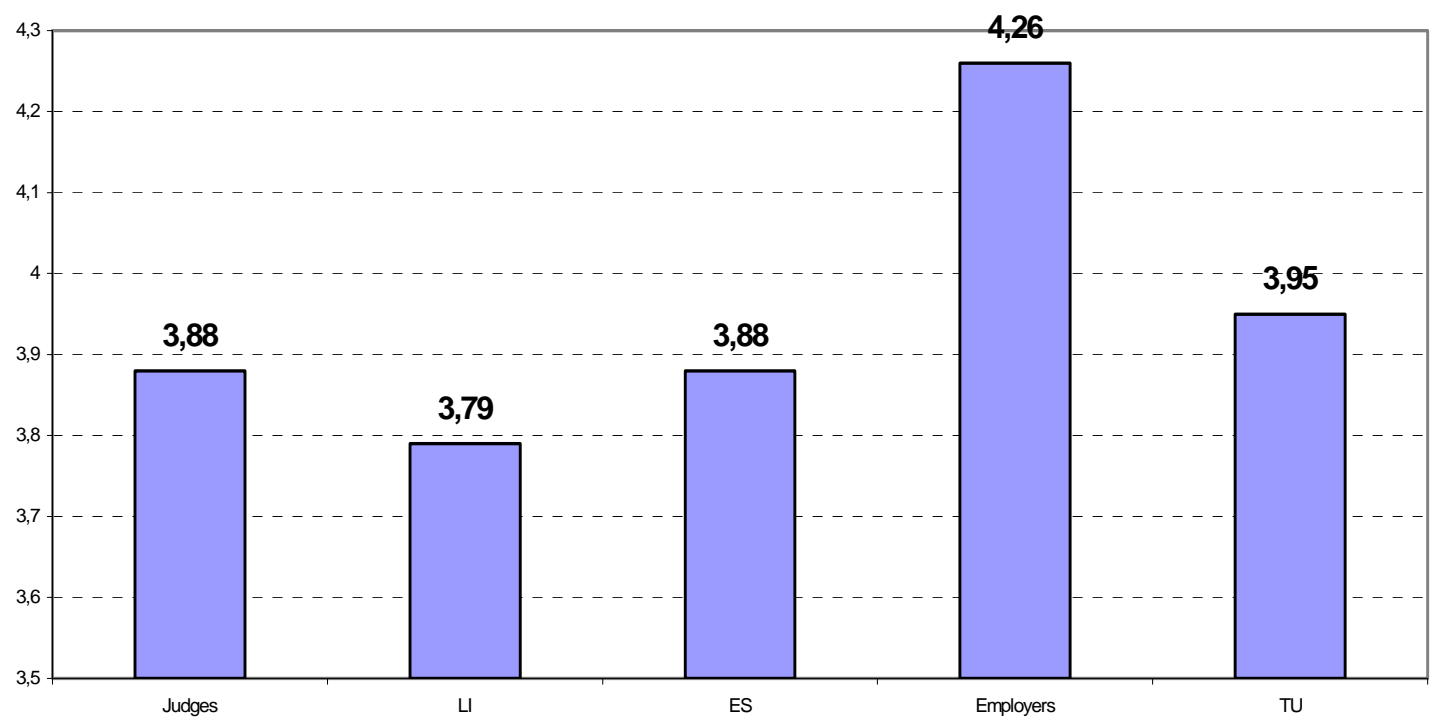

Fig. A2. Distribution of regions by L\&M employment, 2000-2005 (actual EPL coverage) 


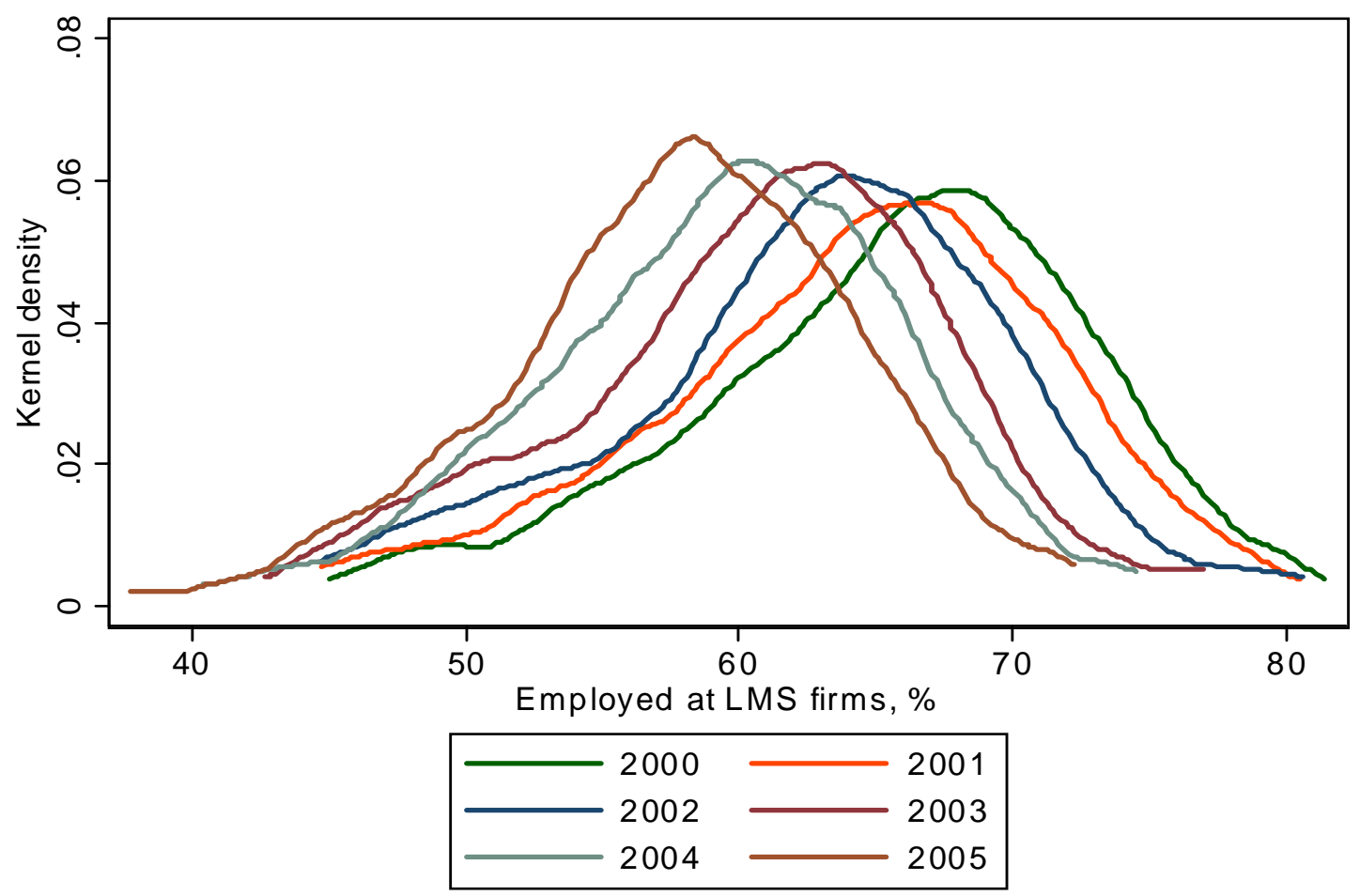


Fig. A3. Distribution of regions by number of inspectors per $100 \mathrm{~L} \& \mathrm{M}$ employees

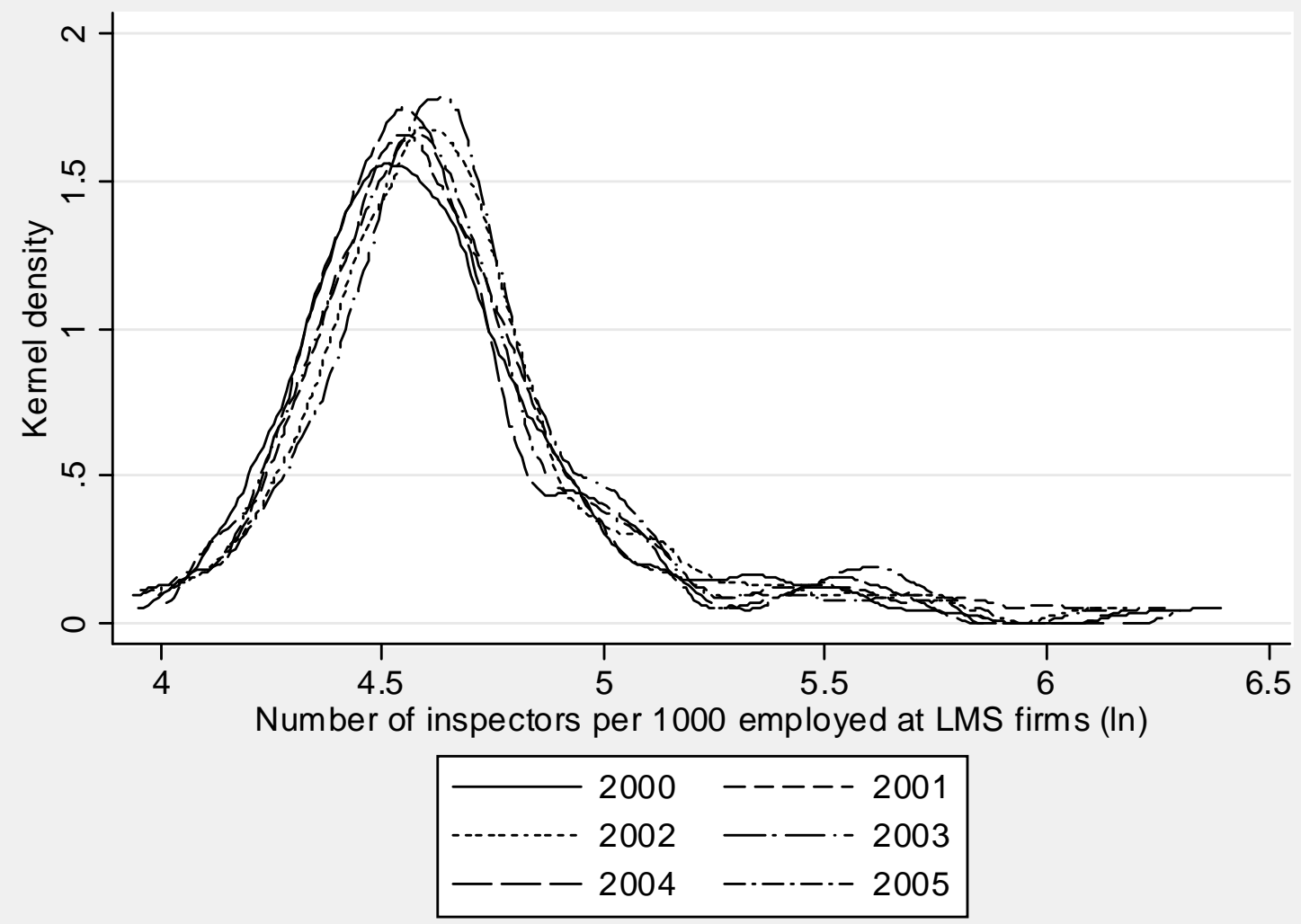

Fig. A4. Distribution of regions by number of labour disputes filed to courts 


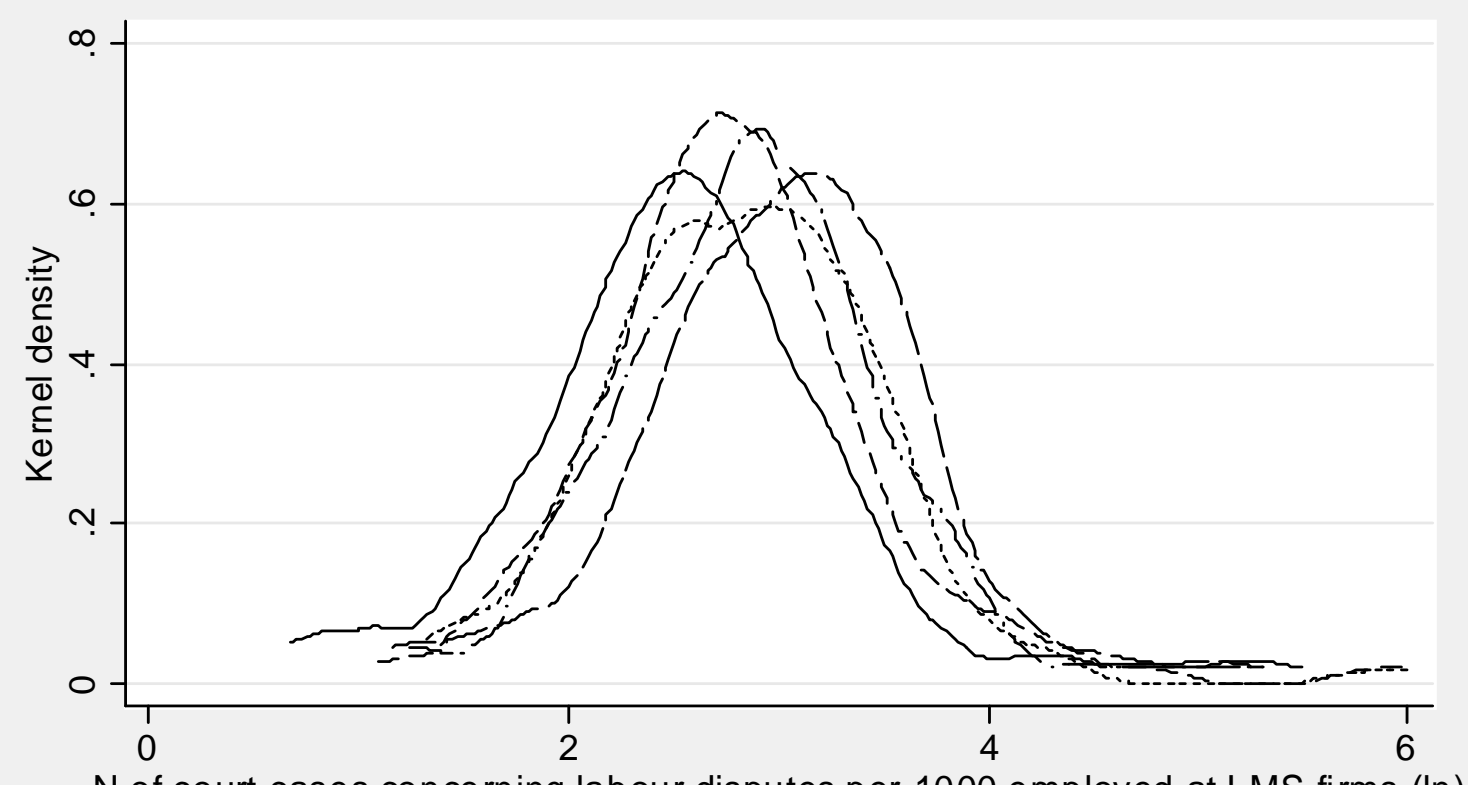

$\mathrm{N}$ of court cases concerning labour disputes per 1000 employed at LMS firms (In)

\begin{tabular}{|c|c|}
\hline 2001 & -----2002 \\
\hline 2003 & -.-- 2004 \\
\hline---2005 & \\
\hline
\end{tabular}


Fig. A5. Simple correlation between institutional capacity of LI ( $N$ of inspectors per L\&M employment) and judicial enforcement ( $\mathrm{N}$ cases filed to courts), 2005

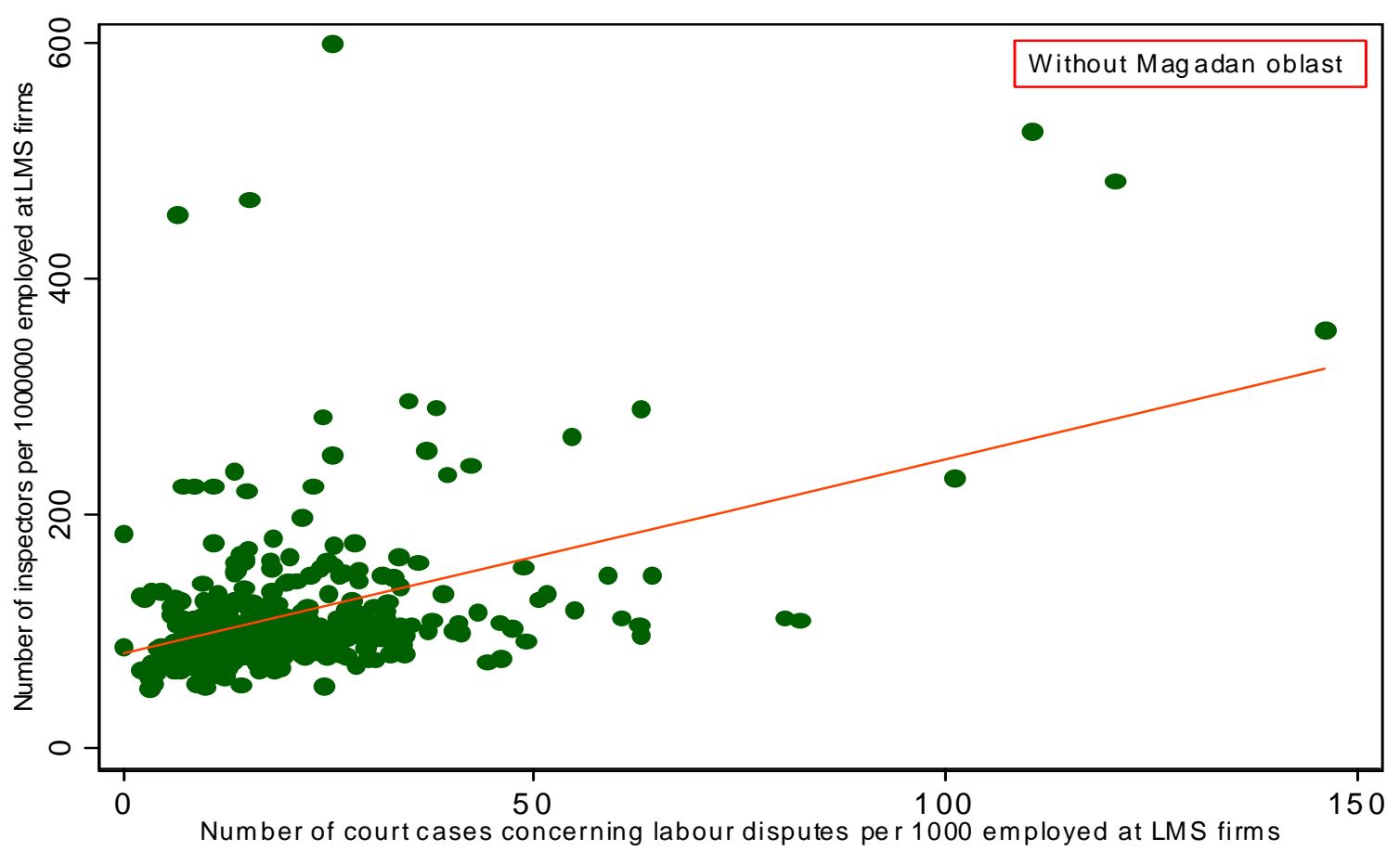

Fig. A6. LI institutional capacity vs unemployment rate

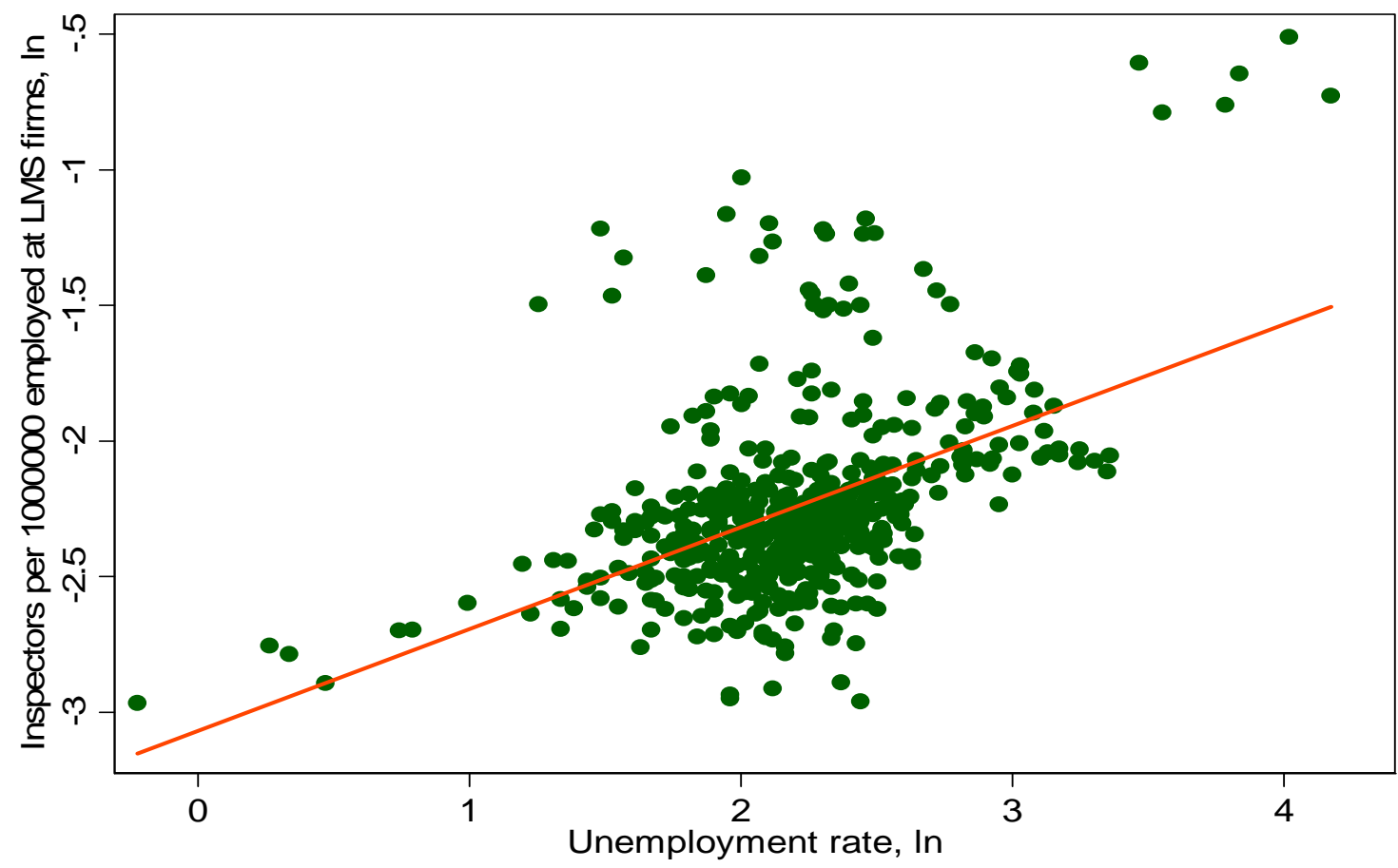


Fig. A7. Judicial enforcement and unemployment

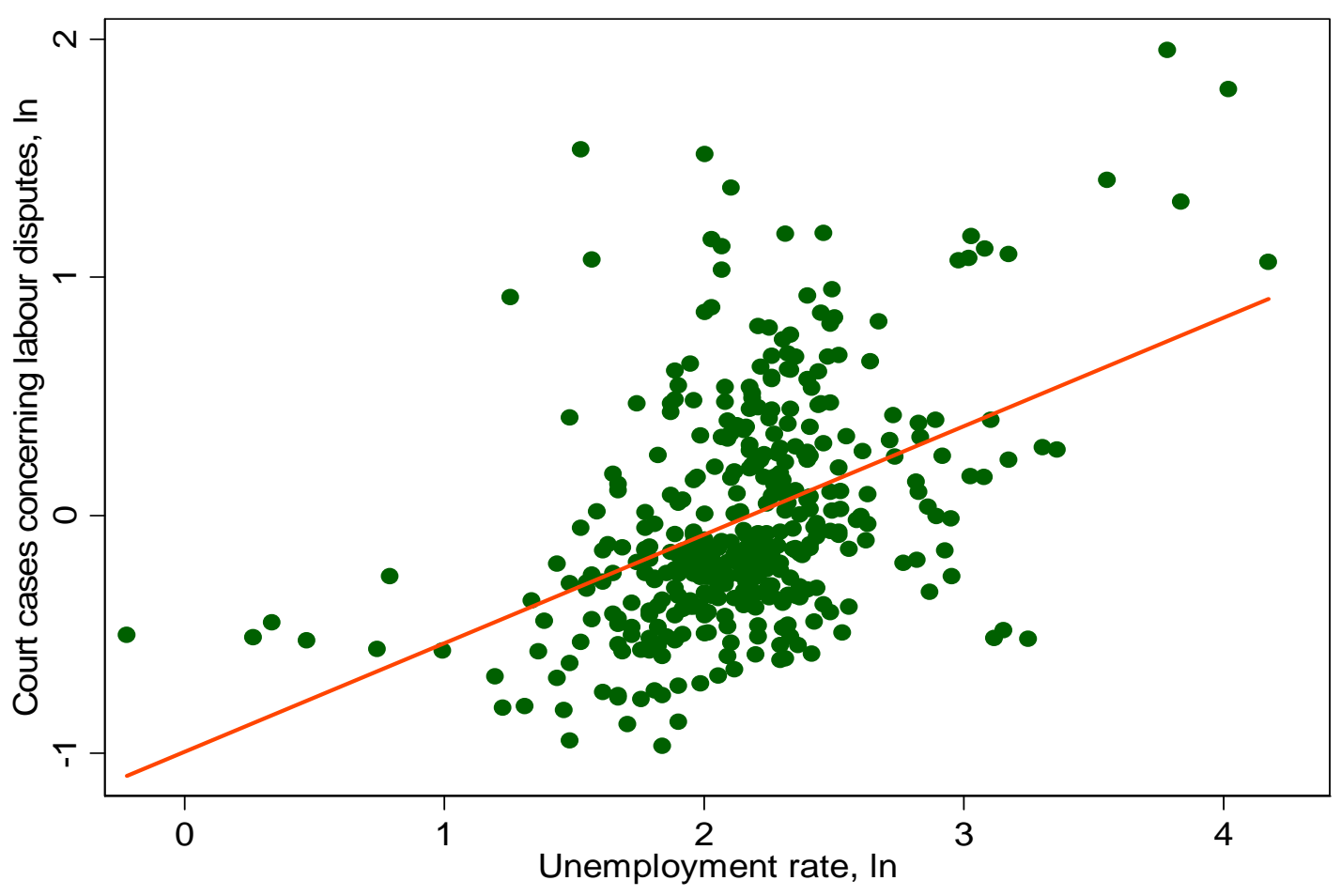

